\title{
A review of equine sepsis
}

\section{S. Taylor}

Veterinary Clinical Sciences, Purdue University, West Lafayette, Indiana, USA. Corresponding author email: taylo248@purdue.edu

Keywords: horse; foal; sepsis; biomarker

\begin{abstract}
Summary
Sepsis is defined as an exaggerated, systemic inflammatory response to infection and is a common condition in horses. Systemic inflammatory response syndrome (SIRS) associated with bacterial infection is a hallmark of sepsis. Sepsis in neonatal foals is a common sequela of failure of passive transfer and, in addition to development of SIRS, may be characterised by bacteraemia, pneumonia, enterocolitis, omphalophlebitis, meningoencephalitis or arthritis. Sepsis in mature horses is most commonly observed secondary to gastrointestinal lesions that result in disrupted mucosa and bacterial translocation into circulation (endotoxaemia). Pleuropneumonia and metritis may also cause sepsis in mature horses. Diagnosis of sepsis is based on SIRS criteria as well as suspected or confirmed infection. Due to the relatively low sensitivity of microbial culture and the subjectivity of sepsis scoring, many sepsis biomarkers are being studied for their usefulness in diagnosis and prognostication of sepsis in horses. Treatment of sepsis requires an intensive care approach that includes antimicrobial drug administration, fluid resuscitation and pressure support, and treatment for inflammation, endotoxaemia and coagulopathy. Early recognition of sepsis and prompt antimicrobial drug treatment are critical for a successful outcome. Multiple organ dysfunction syndrome may occur in severe cases of sepsis, with common manifestations including laminitis and coagulopathies. Although prognosis for septic mature horses depends highly on the primary disease process, the overall survival rate in septic neonatal foals ranges from 26 to $86 \%$, with most studies indicating a survival rate of $45-60 \%$.
\end{abstract}

\section{Introduction}

Despite substantial advances in medical management, sepsis continues to represent a leading cause of illness and death in horses (Hoffman et al. 1992; Cohen et al. 1994; Werners et al. 2005; Peek etal. 2006). The body's systemic inflammatory response to microbial invasion can lead to rapid deterioration despite pathogen control, which presents a challenge to equine practitioners. Several terms have been used to describe sepsis and its sequela. The American College of Chest Physicians and the Society of Critical Care Medicine published a consensus report of definitions in 1992 adopted by veterinary specialists in order to provide accuracy and consistency among practitioners (Bone et al. 1992). The term systemic inflammatory response syndrome (SIRS) is used to describe systemic inflammation that may be caused by infectious agents (e.g. bacteria, fungi, viruses, etc.) or noninfectious causes (e.g. trauma, burns, toxins, acidosis, etc.). When SIRS is the result of infection, it is termed sepsis. The most common infectious agents associated with sepsis are bacteria. If bacteria are present in the blood, the term bacteraemia is used. Although it has been suggested that septicaemia be eliminated from current usage because it does not adequately describe the spectrum of organisms that may invade the blood, it is defined as bacterial infection in the blood in conjunction with SIRS. A frequent complication of SIRS is the development of organ system dysfunction which is called multiple organ dysfunction syndrome (MODS). The term severe sepsis is defined as sepsis associated with hypoperfusion, hypotension or organ dysfunction. If a patient with severe sepsis is hypotensive despite adequate fluid resuscitation, the term septic shock is used. Finally, a syndrome of immunosuppression that may result secondary to SIRS is compensatory anti-inflammatory response syndrome (CARS) and may lead to leucocyte anergy and increased susceptibility to infection.

Endotoxaemia, defined as the presence of Gram-negative bacterial lipopolysaccharide (LPS) within the blood, is a common finding in bacteraemic neonatal foals and is a common sequela of equine gastrointestinal disease, pleuropneumonia and metritis (King and Gerring 1988; Steverink et al. 1994; Ryu et al. 2004; Vinogradov et al. 2008; Hilton and Pusterla 2009; Lopes et al. 2010; Senior et al. 2011). By definition, dead Gram-negative bacteria or fragmented LPS in the blood is not considered 'infection,' but given the similar proinflammatory response, endotoxaemia is considered a subset of sepsis. Horses are exquisitely sensitive to the presence of endotoxin in the blood. Once in the blood stream, LPS may bind circulating LPS-binding protein (LBP), which as a complex then binds the CD14 molecule on monocytic cells. The resulting complex activates toll-like receptor 4 (TLR4) and LPS is transferred to myeloid differentiation protein-2 (MD2) (Werners and Bryant 2012). Pathogen associated molecular patterns (PAMPS), including LPS, may be recognised by pattern recognition receptors (PRRs) other than TLR4, with each recognising specific ligands (Werners and Bryant 2012). Activation of PRRs by PAMPs triggers intracellular signalling which results in increased transcription of several proinflammatory cytokines. These cytokines include tumour necrosis factor alpha (TNF $\alpha$ ), interleukins (IL) 1, IL6, IL8 and IL 12 (Pernerstorfer etal. 1999). Experimental intravenous (i.v.) administration of LPS to horses increases gene expression of IL I, IL6 and IL8 and TNF $\alpha$, and also increases the concentration of IL6 and TNF $\alpha$ proteins in the circulation (Mackay et al. 1991; Mackay and Lester 1992; Nieto et al. 2009). In addition, gene expression of TLR4 and MD2 in equine peripheral WBC has been shown to increase following endotoxin stimulation (Fossum et al. 2012).

Proinflammatory cytokines such as TNF $\alpha$, IL 1 and IL6 induce release of acute phase proteins from the liver. These include fibrinogen, C-reactive protein, mannose-binding lectin, complement, serum amyloid A, haptoglobin, cerruloplasmin and vasoactive amines. Complement and IL8 induce 
neutrophil chemotaxis which results in neutropenia. Simultaneous with WBC activation, endotoxin binds to complement proteins to activate the lectin-dependent and alternative complement pathways, which further promote inflammation through production of peptide products. Intravascular coagulation is initiated primarily through tissue factor activation. The net effects of proinflammatory cytokines, acute phase proteins, procoagulants and vasoactive mediators are hypoperfusion and subsequent tissue hypoxia. Therefore, a relatively common sequela associated with equine endotoxaemia is MODS, which may manifest as laminitis or disseminated intravascular coagulation (DIC) (Parsons et al. 2007). Manifestations of sepsis in neonatal foals and mature (non-neonatal) horses will be discussed separately, followed by diagnosis, treatment, MODS and prognosis of sepsis in equids of all ages.

\section{Manifestations of sepsis in neonatal foals}

\section{Risk factors}

A major risk factor for development of sepsis is failure of passive transfer (FPT) (Jeffcott and Jeffcott 1974; Peek et al. 2006). The 'open' gut that persists for up to $24 \mathrm{~h}$ of age allows absorption of bacteria through specialised enterocytes that, if unchecked by immunoglobulin $G$ (lgG), may overwhelm the innate immune response and cause sepsis. Thus, bacterial translocation typically results in Gram-negative bacteraemia and endotoxaemia (Koterba et al. 1984; Wilson and Madigan 1989; Marsh and Palmer 2001; Borchers et al. 2012). Other routes of microbial invasion include the umbilicus, respiratory and genitourinary tracts and disrupted skin or mucosal barriers. Poor sanitary conditions and improper umbilical care are also risk factors for development of neonatal sepsis. Early detection of FPT is important in reducing morbidity and mortality in neonatal foals and is typically done using a stall-side commercial IgG test (SNAP Foal IgG Test Kit) ${ }^{1}$. This test is highly sensitive for detection of FPT and provides rapid results but is not very specific. In other words, FPT (<8 g/l lgG) is likely to be detected by the SNAP test but many foals with IgG $<8 \mathrm{~g} / \mathrm{lgG}$ do not have FPT (Metzger et al. 2006). Radial immunodiffusion testing provides a more accurate and specific measurement of blood IgG but cost and turnaround time make this test less practical (Metzger et al. 2006).

\section{Bacteraemia}

Sepsis in neonatal foals can manifest in several different ways, with many foals presented with bacteraemia (Russell et al. 2008). Gram-negative bacteria are isolated more commonly than Gram-positive bacteria in bacteraemic neonatal foals but the percentage of Gram-positive isolates has increased significantly over the years (Marsh and Palmer 2001; Corley et al. 2007; Hollis et al. 2008b; Theelen et al. 2014b). Common Gram-negative bacteria isolated from foals include E. coli, Klebsiella pneumoniae, Pseudomonas aeruginosa, Salmonella spp., Enterobacter spp. and Actinobacillus spp. (Wilson and Madigan 1989; Marsh and Palmer 2001; Stewart et al. 2002; Corley et al. 2007). Gram-positive organisms typically consist of Streptococcus spp., Enterococcus spp. and Staphylococcus spp. (Marsh and Palmer 2001; Corley et al. 2007; Hollis et al. 2008b), with the prevalence of Enterococcus spp. increasing (Russell et al. 2008; Theelen et al. 2014b).

\section{Pneumonia}

Septic pneumonia in neonatal foals may occur secondary to haematogenous spread in bacteraemic foals or may occur secondary to aspiration. Abnormal perinatal respiratory development, perinatal hypoxia or immunocompromise may predispose or exacerbate septic pneumonia in some foals (Paradis 1989). In one study, a diagnosis of SIRS was associated with increased pulmonary infiltrates in the caudodorsal lung fields of affected foals, which may have reflected vascular leakage in regions of increased blood flow (Stewart et al. 1987; Bedenice et al. 2003). In a retrospective evaluation of 65 foals with sepsis, 19\% had clinical evidence of pneumonia (Gayle et al. 1998). It is important to note that in many septic foals, respiratory rate and lung auscultation are normal despite pulmonary involvement. Several studies have documented a higher incidence of respiratory disease detected at necropsy compared to ante mortem findings in septic foals (Koterba et al. 1984; Raisis et al. 1996a).

\section{Enterocolitis}

Enterocolitis in neonatal foals is often caused by a primary intestinal pathogen that disrupts the intestinal mucosa, allowing bacterial translocation and subsequent sepsis. Common primary pathogens include Clostridium perfringens types $A$ and C, Clostridium difficile and Salmonella spp. In neonatal foals diagnosed with sepsis, $32-62 \%$ of foals have evidence of enteritis (Raisis et al. 1996a; Gayle et al. 1998). Less common causes of enterocolitis in neonatal foals include rotavirus, Cryptosporidium spp., Strongyloides westeri and coronavirus (Frederick et al. 2009).

\section{Omphalitis/omphalophlebitis}

Bacteria may gain access to the bloodstream of newborn foals via the umbilicus but this is a less common route of entry than the intestinal tract. Of 65 foals diagnosed with sepsis in one study, $13 \%$ had omphalitis or omphalophlebitis (Gayle etal. 1998). The most common organism isolated from infected umbilical remnants is E. coli (Adams and Fessler 1987; Rohdich et al. 2009). A common complication associated with omphalitis or omphalophlebitis is development of a patent urachus, which occurred in 11 of 16 foals in one study (Adams and Fessler 1987).

\section{Meningoencephalitis}

Meningoencephalitis is a rare but severe manifestation of neonatal foal sepsis. Of 9 neonatal foals with confirmed bacterial meningoencephalitis that presented to a referral institution, all demonstrated abnormal mentation, while recumbency and weakness were observed in $80 \%$ of foals (Viu et al. 2012). Other clinical signs included decreased suckle reflex $(67 \%)$, abnormal pupillary light reflexes $(60 \%)$ and seizures and/or nystagmus (40\%). The most frequently isolated organism was E. coli (Viu et al. 2012).

\section{Septic arthritis}

Haematogenous spread of bacteria to joints has been reported to occur in 14-38\% of neonatal foals with sepsis (Gayle et al. 1998; Corley et al. 2007). Approximately $50 \%$ of foals with septic arthritis have more than one joint affected, with the tarsocrural and femoropatellar joints more commonly seeded (Meijer et al. 2000). Orthopaedic infection should be 
considered the primary differential in a foal that exhibits lameness and/or joint effusion (Sanchez 2005).

\section{Manifestations of sepsis in mature horses}

\section{Gastrointestinal disease}

Equine gastrointestinal disease that results in ischaemia or inflammation may lead to loss of mucosal integrity and subsequent migration of bacteria and LPS into the circulation. It has been shown that up to $29 \%$ of horses presenting for colic to a referral institution had detectable LPS in the circulation and that increased levels of blood LPS were positively correlated with mortality (Senior et al. 2011). Endotoxaemia can occur secondary to infectious enterocolitis or strangulating gastrointestinal lesions that lead to peritonitis. Common infectious causes of colitis in adult horses include equine neorickettsiosis (Potomac horse fever), Clostridium perfringens, Clostridium difficile and Salmonella spp. Bacteraemia caused by Neorickettsia risticii can induce SIRS in cases of equine neorickettsiosis. In a retrospective study investigating factors associated with survival in 44 horses with equine neorickettsiosis, severity of colitis that was reflected by electrolyte loss and prerenal azotaemia was predictive of survival (Bertin etal. 2013). C. perfringens type $C$ and, less commonly, type $A$, can be a primary cause of enterocolitis in adult horses, while $C$. difficile is often associated with antimicrobial use (Feary and Hassel 2006). Faecal samples from 43 adult horses with clinical signs of acute colitis were cultured for anaerobic bacteria; C. perfringens and C. difficile were isolated in 40 and $5.4 \%$ of cases, respectively, while Salmonella spp. were not cultured in any (Gohari et al. 2014). Salmonella spp. (may) be transiently shed in faeces of normal horses, but can cause enterocolitis in susceptible animals (Schott et al. 2001; Ernst et al. 2004). Equine coronavirus is a newly emerging infectious disease in the United States that causes anorexia, lethargy, fever and, occasionally, diarrhoea. Although the mortality rate is low in affected adult horses, deterioration of clinical signs may be associated with gastrointestinal translocation of bacteria and subsequent sepsis (Pusterla et al. 2013). Equine duodenitis-proximal jejunitis (DPJ) is an inflammatory condition of the small intestine that often results in severe endotoxaemia-associated SIRS (Davis et al. 2003). Distinguishing DPJ from a surgical small intestinal lesion can be challenging, as strangulating obstructive lesions can cause similar clinical signs including SIRS secondary to endotoxaemia, gastric reflux and colic. In a prospective study, $14 \%$ of horses with strangulating small intestinal lesions requiring resection and anastomosis were bacteraemic, although this percentage may have been falsely low given the poor sensitivity of blood culture (Hurcombe et al. 2012).

\section{Pneumonia}

Septic pneumonia may occur secondary to bacterial, viral or fungal infection. The most common respiratory tract disease that results in sepsis is pleuropneumonia, with clinical signs of SIRS typically evident during the acute stage of disease. The most frequently isolated aerobic bacteria in cases of pleuropneumonia are $\beta$-streptococcus sp., Pasteurella sp., E. coli and Enterobacter sp. (Sweeney et al. 1991). Anaerobic species most commonly isolated include Bacteroides sp. and Clostridium sp. (Sweeney etal. 1991). The survival rate for horses with aerobic bacterial infections is higher than that of horses with anaerobic or mixed aerobic and anaerobic infections and may be affected, in part, by the presence and severity of sepsis (Sweeney et al. 1985, 1991).

\section{Metritis}

Septic metritis in horses is usually secondary to retained fetal membranes, with ascending bacterial infection occurring hours to days after parturition (Hudson et al. 2005). Risk factors for retention of fetal membranes include mare age (Provencher et al. 1988), breed (Sevinga et al. 2004), both short and long gestation (Sevinga et al. 2004), low serum calcium concentration within $12 \mathrm{~h}$ post partum (Sevinga et al. 2002) and caesarean section (Abernathy-Young et al. 2012). If bacteria are absorbed into the circulation from the infected uterus, sepsis can result. In addition to signs of SIRS, horses with septic metritis may also exhibit red-brown, foetid discharge from the cervix or vulva. Although contagious equine metritis (Taylorella equigenitalis) is a primary cause of metritis in mares, it does not typically cause systemic infection or sepsis (Erdman et al. 2011).

\section{Diagnosis}

Although criteria for SIRS have not been definitively defined in veterinary medicine, several equine studies have extrapolated the SIRS definition from human medicine (Corley et al. 2005; Schwarz et al. 2012; Aguirre et al. 2013; Epstein et al. 2013; Borde et al. 2014). The definition of SIRS in people is based on physiological parameters including body temperature, heart rate, respiratory rate and abnormal leucocyte count (Bone et al. 1992). The presence of 2 of the following abnormalities is considered diagnostic for SIRS:

1) Hyperthermia or hypothermia.

2) Tachycardia.

3) Tachypnoea or hyperventilation.

4) Leucopenia, leucocytosis, or $>10 \%$ band neutrophils.

Although these parameters are nonspecific, the SIRS criteria do not apply when other noninflammatory causes of these clinical signs are present, such as pain, heat stress or chemotherapy (Bone et al. 1992). However, definitive diagnosis of bacterial sepsis is obtained through microbial culture. Unfortunately, culture and antimicrobial susceptibility results are usually not available until more than $48 \mathrm{~h}$ after admission and consequently, empirical treatment is often instituted prior to diagnosis. Early antimicrobial treatment, although warranted in suspect cases, may impede the sensitivity of culture as a diagnostic test for sepsis. In addition, false negative blood culture results may be due to low numbers of circulating bacteria or a relatively low volume of blood for culture and varying blood culture systems may yield inconsistent results (Wilson and Madigan 1989). A weighted sepsis scoring system is currently used as a diagnostic tool for sepsis in neonatal foals, but demonstrates a relatively low sensitivity and specificity (Brewer and Koterba 1988; Corley and Furr 2003). Although clinicopathological findings such as leucopenia, neutropenia with a degenerative left shift and neutrophil toxicity have been associated with sepsis in horses, lack of test specificity limits their usefulness in contributing to a diagnosis of sepsis (Hurcombe et al. 2008). However, with regard to predicting survival, white blood cell (WBC) counts $\left(>6.0 \times 10^{9} / \mathrm{I}\right)$ and neutrophil counts $\left(>4.0 \times 10^{9} / \mathrm{I}\right)$ are significantly associated with increased odds of survival in 
septic foals (Gayle et al. 1998). Elevated plasma fibrinogen has been associated with in utero infection and is associated with nonsurvival, but is also a nonspecific indicator of inflammation (Koterba et al. 1984). Hyperfibrinogenaemia was observed in $89 \%$ of neonatal foals with confirmed meningoencephalitis (Viu et al. 2012). Increased blood L-lactate concentration and persistence of hyperlactataemia are associated with nonsurvival in horses with systemic illness, but a clear association with bacteraemia is lacking (Castagnetti et al. 2010). Evaluation of blood L-lactate concentration at a single time point is a poor predictor of sepsis (Borchers et al. 2012), but is consistently elevated in foals with meningoencephalitis (Viu et al. 2012). Cytokine profiles in septic horses have varied widely among studies and are not currently utilised for diagnosis or prognostication of equine sepsis in neonatal foals (Pusterla et al. 2006; Gold etal. 2007; Burton et al. 2009; Castagnetti et al. 2012).

In recent years, biological laboratory markers (biomarkers) have become important in diagnosing sepsis, guiding antimicrobial therapy and assessing response to therapy in human medicine (Mussap etal. 2013). Over 170 different compounds have been tested as potential biomarkers in human sepsis and biomarker development is an ongoing area of research within the global sepsis field (Pierrakos and Vincent 2010). Proteins recently investigated for their potential use as biomarkers for sepsis include include serum amyloid A (SAA), C-reactive protein (CRP), haptoglobin (Hp), soluble CD14 (sCD 14), adrenomedullin (AM) and procalcitonin (PCT) (Taylor 2014).

Serum amyloid A is a major acute phase protein in horses that rapidly increases in response to inflammation (Chavatte et al. 1992). There is evidence that infections are particularly effective in inducing a strong SAA response, suggesting that SAA concentration may be useful in distinguishing infectious from noninfectious disease (Pepys et al. 1989; Vandenplas et al. 2005; Kjelgaard-Hansen and Jacobsen 2011). Serum amyloid A has been advocated as a useful biomarker in the diagnosis of equine neonatal sepsis, but periparturient events may influence SAA concentrations (Chavatte et al. 1992; Stoneham et al. 2001; Duggan 2008; Paltrinieri etal. 2008). Initial studies in neonatal foals suggest that quantification of SAA can differentiate infectious from noninfectious illness (Chavatte et al. 1992; Stoneham et al. 2001). Concentrations of SAA have been shown to be increased in adult horses with bacterial pneumonia, influenza and septic arthritis (Hulten et al. 1999; Hulten and Demmers 2002; Jacobsen et al. 2006). In one study, clinically abnormal adult horses demonstrated a 20.5-fold increase in median SAA compared to a relatively low $(<2$-fold $)$ increase in median WBC count and median plasma fibrinogen concentration (Belgrave et al. 2013). Increased concentrations of SAA have been documented in mares with experimentallyinduced endometritis, with serum concentrations correlating well with endometrial SAA expression (Christoffersen et al. 2010; Coutinho da Silva et al. 2013).

C-reactive protein is a well established biomarker of infection and inflammation in human sepsis (Keshet et al. 2009; Hofer etal. 2012). During the acute phase response to bacterial infection in people, serum CRP concentration increases within hours and can reach 1000-fold levels (Hofer et al. 2012). Levels remain elevated during persistent infection and then decrease rapidly (Vigushin et al. 1993). In man, serum CRP concentration may increase with many noninfectious inflammatory conditions, including rheumatoid arthritis, acute myocardial infarction and pancreatitis (Vincent et al. 2011). A recent study evaluating plasma CRP concentrations in 40 septic, 40 sick nonseptic and 39 healthy control foals failed to demonstrate an increase in any group (Taylor et al. 2013). The accuracy of a single measurement for diagnosis of sepsis varies widely, with the ideal timepoint for measurement and peak levels in horses unknown (Pourcyrous et al. 1993; Laborada et al. 2003). Serum CRP concentrations have not been shown to increase in adult horses with recurrent airway obstruction or exercise-induced inflammation (Cywinska et al. 2012; Lavoie-Lamoureux et al. 2012) and CRP has not been evaluated in adult horses with sepsis.

Haptoglobin is a protein produced in the liver and functions to bind free haemoglobin following intravascular haemolysis. Serum $\mathrm{Hp}$ concentrations have been shown to decrease following haemolysis and increase following acute inflammation in several species, including horses (Eurell et al. 1993; Hulten etal. 2002). In a human study, bacteraemic patients had higher serum $\mathrm{Hp}$ concentrations compared to patients without infection, suggesting that serum $\mathrm{Hp}$ concentration may have clinical utility in the diagnosis of sepsis (Chavez-Bueno et al. 2011). A recent study investigating the acute phase response in critically ill neonatal foals found that 40 septic foals exhibited significantly lower plasma $\mathrm{Hp}$ concentrations than 37 healthy foals, but there was no evidence of increased haemolysis in the septic group (Zabrecky et al. 2013). In adult horses, serum Hp concentrations have been shown to increase after elective and nonelective surgery and in horses affected with recurrent airway obstruction (Pollock et al. 2005; Lavoie-Lamoureux et al. 2012).

Membrane-bound CDI4 is found on the surface of monocytes and macrophages. Binding of CDI4 to the LPS/LPS-binding protein complex triggers activation of TLR4, which initiates transcription of proinflammatory cytokines. A soluble form of CD14 (sCD14) can be found in serum and is thought to be a product of membrane-bound CD14 released from cell surfaces (Bazil et al. 1986; Wagner et al. 2013). Soluble CD14 can bind circulating LPS and transfer LPS to plasma lipoproteins, thereby serving as an anti-inflammatory protein (Kitchens and Thompson 2005). Elevated serum concentrations of sCDI4 have been reported in man with acute inflammation and sepsis and are likely a reflection of LPS-induced cell activation (Kitchens et al. 2001). In one study, sCDI4 was found to be elevated in serum of 15 septic foals compared to 15 healthy foals (Wagner et al. 2013). In a second study, SCD 14 was found to be significantly increased in serum from 55 adult horses with diseases commonly associated with endotoxaemia compared to 23 healthy controls; however, sCD14 concentrations did not correlate with outcome (Silva et al. 2013).

Adrenomedullin is a circulating hormone synthesised by the adrenal medulla, endothelial cells and vascular smooth muscle cells (Kitamura et al. 1993; Hinson et al. 2000). This peptide facilitates tissue perfusion through potent vasodilatory and inotropic effects (Nishikimi et al. 2003; Gibbons et al. 2007) and has been shown to increase rapidly following the onset of sepsis in man and rodents (Wang et al. 1998; Koo et al. 2001). Adrenomedullin is thought to contribute to hyperdynamic circulation characterised by decreased mean arterial blood pressure, decreased systemic vascular resistance and compensatory increases in cardiac output and stroke volume (Wang et al. 1998; Koo et al. 2001). In man, plasma AM levels increase with various clinical diseases, with up to 50-fold 
increases observed in septic patients (Ueda et al. 1999; Gibbons et al. 2007; Oncel et al. 2012). Although AM has not been evaluated in adult horses, a recent study investigated plasma AM concentration in 3 groups of neonatal foals: septic, sick nonseptic and healthy controls (Toth et al. 2014). Ninety critically ill foals (42 septic, 48 sick nonseptic) and 61 healthy foals were included in the study. There was a 6-fold increase in the median plasma AM concentration in critically ill foals compared to healthy foals $(\mathrm{P}<0.0001)$, but $\mathrm{AM}$ levels were not associated with sepsis $(P=0.71)$ or survival $(P=0.051)$. Plasma AM concentrations of $0.041 \mathrm{ng} / \mathrm{ml}$ provided a test sensitivity of $91 \%$ and specificity of $54 \%$ to predict illness, suggesting that plasma AM concentration may serve as a marker of health in foals.

In human medicine, serum procalcitonin concentrations are increased in patients with sepsis and are particularly useful in distinguishing bacterial sepsis from other forms of infection (Aikawa et al. 2005). Elevated serum PCT concentrations can be observed with noninfectious inflammatory diseases, but studies in man suggest that PCT is a more reliable marker of sepsis than CRP (Luzzani etal. 2003). To date, PCT concentrations in veterinary species have not been useful in the diagnosis of sepsis. A study investigating the expression of molecular markers in blood of neonatal foals with sepsis found no difference in PCT between 21 healthy foals and 49 sick foals (Pusterla et al. 2006).

Other diagnostic tests in neonatal foals include ultrasonography of the umbilicus, since external umbilical structures may appear normal even in foals with abscessed umbilical remnants, and thoracic imaging if septic pneumonia is suspected. Other tests may be required based on the manifestation of sepsis in an individual patient. For example, CSF cytology and culture are indicated in neonatal foals with suspected meningoencephalitis, while joint fluid cytology and culture are indicated in foals with suspected septic arthritis. Blood or faecal PCR are indicated for horses with suspected equine neorickettsiosis and anaerobic faecal culture and analysis may be necessary in horses with diarrhoea when clostridial enterocolitis and/or salmonellosis are suspected. Finally, tracheal wash and/or pleural fluid culture are indicated in horses with pleuropneumonia and culture of uterine fluid may be warranted in cases of suspected metritis.

To summarise, definitive diagnosis of sepsis requires detection of the clinical parameters of SIRS as well as confirmation of bacterial infection. Given the high risk of bacteraemia in neonatal foals, blood cultures are performed routinely and positive results often confirm a diagnosis of sepsis. In mature horses (and occasionally in neonatal foals), the presence of SIRS in addition to isolation of bacteria from a local infection are used to diagnose sepsis. Due to the insensitivity of microbial culture, the presence of SIRS and a strong suspicion of infection may justify a diagnosis of sepsis.

\section{Treatment}

Treatment of sepsis requires an intensive care approach that includes antimicrobial drug administration, fluid resuscitation and blood pressure support, and treatment for inflammation, endotoxaemia and coagulopathy. Early recognition of sepsis and prompt antimicrobial drug treatment are critical for a successful outcome. Initially, a broad-spectrum bactericidal approach should be based on prediction of likely organisms (given the hospital or region's recent history) and should not be delayed pending microbial culture results if there is a high suspicion of sepsis. Based on several antimicrobial sensitivity studies in foals with bacteraemia, the current recommendation for empirical treatment of suspected neonatal foal sepsis is a combination of an aminoglycoside (amikacin: $21-25 \mathrm{mg} / \mathrm{kg}$ bwt i.m. or i.v. q. $24 \mathrm{~h}$; gentamicin: $6.6 \mathrm{mg} / \mathrm{kg}$ bwt i.m. or i.v. q. $24 \mathrm{~h}$ ) with penicillin $\mathrm{G}$ (sodium/potassium: 22,000-44,000 iu/kg bwt i.v. q. $6 \mathrm{~h}$; procaine: $22,000-44,000 \mathrm{iu} / \mathrm{kg}$ bw $\mathrm{i} . \mathrm{m}$. q. $12 \mathrm{~h}$ ), ampicillin sodium (15-50 mg/kg bwt i.m. or i.v. q. 6-8 h), or a thirdgeneration cephalosporin (ceftiofur: $2-5 \mathrm{mg} / \mathrm{kg}$ bwt i.m. or i.v., q. 6-12 h) (Wilson and Madigan 1989; Marsh and Palmer 2001; Sanchez 2005; Theelen etal. 2014a). Targeted therapy should be implemented based on sensitivity results typically available 4-7 days after submission. Aminoglycosides should be avoided in foals with hypovolaemia or nephropathy and fluoroquinolones (e.g. enrofloxacin: $5-7 \mathrm{mg} / \mathrm{kg}$ per os or i.v. q. $24 \mathrm{~h})$ should be reserved for those cases with resistance to other antimicrobials given the risk of arthropathy (Davenport et al. 2001). Appropriate antimicrobial treatment of sepsis in mature horses is based on culture and antimicrobial susceptibility in cases of pleuropneumonia and metritis, while oxytetracycline (6.6-15 mg/kg bwt i.v. q. 12-24 h) is considered the treatment of choice for horses suspected of having equine neorickettsiosis (Bertin et al. 2013). Horses with antimicrobial-associated colitis or salmonellosis are typically not treated with antimicrobials, but this may be necessary in severe cases in order to prevent bacterial translocation and subsequent bacteraemia.

Fluid therapy is an important component of therapy for horses with hypovolaemia, hypotension, septic shock, or acid/base/electrolyte disorders. Initial choices include a combination of isotonic crystalloids (i.e. Plasmalyte, Normosol, Lactated Ringers Solution) and colloids (plasma: $20 \mathrm{ml} / \mathrm{kg}$ bw i.v.; hydroxethyl starch: $10 \mathrm{ml} / \mathrm{kg}$ bwt i.v.). Hyperimmune plasma is often the colloid of choice since FPT is not an uncommon finding in septic foals, and can also be used to address low colloidal oncotic pressure and hypovolaemia. Equine plasma specifically enriched with anti-endotoxin antibodies has been shown to increase survival in sick neonatal foals compared to foals receiving hyperimmune equine plasma (Peek et al. 2006). Due to the relatively high cost of plasma (currently $\$ 150 / I$ ), synthetic colloids may be the only affordable choice for some owners. It is important to note, however, that hydroxyethyl starches are no longer recommended for treatment of sepsis in man due to increased renal adverse effects and some studies indicating an increase in mortality (Perner et al. 2012; Mutter et al. 2013).

For horses that present in septic shock, fluids should be administered initially at a 'shock dose' (20 ml/kg bwt) bolus over $30 \mathrm{~min}$ and may need to be repeated 1-2 times depending on response to therapy. Once normovolaemia is achieved, a maintenance fluid rate of $60-100 \mathrm{ml} / \mathrm{kg}$ bwt/day is typically adequate to maintain hydration, although this may need to be adjusted for ongoing losses in some cases. During fluid therapy, it is important to monitor for clinical signs of oedema, urine output, vital signs and extremity temperature. Clinicopathological values that should be routinely monitored in neonatal foals include blood glucose, arterial blood gas analysis and electrolyte concentrations.

Special considerations in neonatal foals include the importance of reassessment and care to prevent overhydration. In addition, supplementation of isotonic crystalloids with dextrose is often necessary since many foals 
present with hypoglycaemia. Judicious monitoring of blood glucose during dextrose supplementation is important, as many foals develop subsequent hyperglycaemia. Sick foals with blood glucose concentrations $<2.8 \mathrm{mmol} / \mathrm{l}$ or $>10 \mathrm{mmol} / \mathrm{l}$ were less likely to survive in one study, highlighting the importance of maintaining euglycaemia in critically ill foals (Hollis et al. 2008a).

If multiple boluses of i.v. fluids are not successful in restoring tissue perfusion, inopressor therapy should be initiated. The drugs used most commonly to support perfusion are dobutamine (1-15 $\mu \mathrm{g} / \mathrm{kg}$ bwt/min i.v. continuous rate infusion [CRI]), dopamine $(1-20 \mu \mathrm{g} / \mathrm{kg}$ bwt $/ \mathrm{min}$ i.v. CRI), norepinephrine $(0.05-1 \mu \mathrm{g} / \mathrm{kg} / \mathrm{min}$ i.v. CRI), epinephrine $(0.01-0.05 \mathrm{mg} / \mathrm{kg}$ bwt i.v.) and vasopressin (0.0005-0.001 IU/kg/min i.v. CRI). In general, dobutamine is a good first choice and $5 \mu \mathrm{g} / \mathrm{kg}$ bwt $/ \mathrm{min}$ is a reasonable starting point for horses not in septic shock. For those with evidence of shock, up to $15 \mu \mathrm{g} / \mathrm{kg} \mathrm{bwt} / \mathrm{min}$ may be used. The other adrenergic agonists may be tried if dobutamine is unsuccessful. It is important to remember that the goal of therapy is to return perfusion to minimally acceptable levels and not to try to achieve normal perfusion.

Nonsteroidal anti-inflammatory drugs (NSAIDs) are important to address endotoxaemia and inflammation associated with SIRS. Compared to phenylbutazone, flunixin meglumine at $0.25 \mathrm{mg} / \mathrm{kg}$ bwt i.v. q. $8 \mathrm{~h}$ has been shown to be more effective in controlling inflammation associated with endotoxin in adult horses, but studies in foals are lacking (Semrad et al. 1987). Adverse effects such as gastroduodenal ulceration and renal papillary necrosis may occur, especially in dehydrated animals, so caution should be used when administering these drugs.

Steroid use in sepsis is controversial. It is well accepted in human medicine that high doses of corticosteroids are contraindicated in patients with sepsis and that dexamethasone leads to harmfully prolonged suppression of the hypothalamic-pituitary axis (HPA) (Cronin et al. 1995; Batzofin etal. 2011). Hydrocortisone therapy at low to moderate doses is currently recommended for septic shock in selected human patients (Marik et al. 2008). There is some evidence that neonatal foals exhibit cortisol insufficiency in critical illness, but recent studies demonstrate the lack of understanding of the HPA axis in septic horses (Hart et al. 2009, 2011 , 2012). Thus, to date, there is no evidence from which to make recommendations regarding corticosteroid use in septic horses.

Polymyxin B is a peptide antimicrobial drug that exhibits anti-endotoxin effects by directly binding to the lipid A portion of LPS (Morrison and Jacobs 1976). In an ex vivo model of endotoxaemia, polymyxin B was found to inhibit TNF $\alpha$ activity from LPS-stimulated monocytes (Parviainen et al. 2001). In vivo studies have shown beneficial effects of polymyxin B after experimental induction of endotoxaemia in foals and adults, supporting its use in clinical cases (Barton et al. 2004; Wong et al. 2013). Caution must be used in horses with hypovolaemia or concurrent kidney disease given the potentially nephrotoxic properties of the drug. The recommended dosage for polymyxin B is $1000-6000 \mathrm{u} / \mathrm{kg}$ bwt q. 8-12 h.

Ethyl pyruvate (EP) is a derivative of pyruvate that exerts anti-inflammatory effects by blocking binding of DNA to NFk $\beta$ and inhibiting expression of proinflammatory cytokines (Fink 2003; Mizutani et al. 2011). In adult horses, EP has been shown to inhibit clinical signs of endotoxaemia and decrease proinflammatory gene expression following LPS infusion, without adverse effects (Cook et al. 2011; Schroeder et al. 2011; Jacobs et al. 2012). Although EP may have therapeutic application in endotoxaemic horses, it has not been tested in clinical cases and is not currently available in a clinical setting.

Anti-gastroduodenal ulcer drugs may be used in adult horses that are considered high-risk for gastric ulceration due to stress or anorexia. Septic adult horses may benefit from anti-ulcer medications, which should be recommended on an individual basis. The use of these drugs is controversial in septic neonatal foals. Recent reports suggest that these medications do not significantly decrease risk of ulcer formation and may increase the risk of diarrhoea (Elfenbein and Sanchez 2012; Furr et al. 2012). Therefore, gastroduodenal ulcer prophylaxis in foals should be instituted on an individual basis.

Other treatments depend on prevailing circumstances for each individual case and may include intranasal oxygen insufflation and surgical treatment of septic joints or umbilical infections. Bronchodilators such as albuterol (720 $\mu \mathrm{g}$ q. 4-6 h, inhaler) may be useful in horses with septic pleuropneumonia. Systemic low dose corticosteroid treatment may be beneficial in modulating SIRS in septic horses, but further studies are warranted before specific recommendations can be made (Hart and Barton 2011).

\section{Multiple organ dysfunction syndrome (MODS)}

Dysfunction of 2 or more organs as a sequela to sepsis or septic shock is defined as MODS. Although it may not be appropriate to classify the hoof as an 'organ,' it is reasonable to include laminitis in the MODS criteria given that widespread inflammation and coagulation disorders that lead to MODS in patients with sepsis/septic shock also lead to laminitis in carbohydrate and black walnut-associated laminitis (Parsons et al. 2007; Visser and Pollitt 2011; Kwon et al. 2013). Similar to SIRS criteria, MODS criteria have not been validated in the horse. Extrapolation from human medicine (with the exception of laminitis) defines MODS as dysfunction of 2 or more of the following systems: laminitis, haemostatic, neurological, renal, respiratory, intestinal, haemodynamic and hepatic (Bone etal. 1992). Laminitis and haemostatic dysfunction (coagulopathies) will be discussed further.

\section{Laminitis}

In adult horses, one of the most devastating complications of sepsis is the development of acute laminitis. In a retrospective study comparing 73 hospitalised horses that developed laminitis with 146 that did not, the diagnosis of endotoxaemia was found to be the only factor significantly associated with laminitis (Parsons et al. 2007). Although hypoxia and laminar microthrombi formation are suspected to be involved in the pathophysiology of endotoxin-mediated laminitis, several attempts to induce laminitis by experimental infusion of LPS have not been successful (Turek et al. 1985; Ward et al. 1987; MacKay et al. 1991; MacKay and Lester 1992; Tadros and Frank 2012). Laminitis may also be induced by hyperglycaemia and hyperinsulinaemia (insulin resistance) (de Laat et al. 2012; Knowles et al. 2012). In a retrospective analysis of 44 horses diagnosed with equine neorickettsiosis, laminitis was present in $38 \%$ of horses, $88 \%$ of which were affected in all 4 feet (Bertin et al. 2013). Prophylactic treatment with digital hypothermia has been shown to decrease the incidence of laminitis in 
horses with colitis and may improve outcome in horses with other forms of sepsis (Kullmann et al. 2013).

\section{Disseminated intravascular coagulopathy (DIC)}

A consequence of sepsis is coagulation abnormalities, which can be dynamic and complicated. Systemic inflammation associated with sepsis can cause widespread damage to the endothelium, which promotes coagulation. This hypercoagulable state can lead to microthrombi formation, ischaemia and MODS (Taylor et al. 2001). As coagulation factors are consumed, the patient enters a hypocoagulable phase characterised by excessive bleeding (Epstein 2014). In human patients with sepsis, administration of heparin is recommended for those patients in a hypercoagulable state (Zimmerman 2004). Heparin has been shown to decrease the incidence of laminitis and increase survival in adult horses with hypercoagulable DIC, but heparin may increase bleeding in the hypocoagulable state; thus, its use in sepsis is controversial as these states may not be easily decipherable (Welch et al. 1992; Cohen etal. 1994). Low molecular weight heparin (LMWH; dalteparin) has reportedly fewer side effects than unfractionated heparin in horses, with the recommended dosage of $50 \mathrm{iu} / \mathrm{kg}$ bwt q. $24 \mathrm{~h} \mathrm{SC}$ (Feige et al. 2003). The incidence of DIC in septic foals can reach up to $50 \%$ and is associated with nonsurvival (Armengou et al. 2008; Bentz et al. 2009). Neonatal foals require a higher dosage of LMWH than adults to achieve anticoagulant activity blood levels and dosing at $100 \mathrm{iu} / \mathrm{kg}$ bwt q. 24 h subcutaneously appeared safe in a clinical study (Armengou etal. 2010). Hyperimmune equine plasma containing coagulation factors may be beneficial in treating or preventing the hypocoagulable state of DIC (Welch et al. 1992). In both neonatal and mature horses, treatment of the underlying disease is the most important therapy for DIC.

\section{Prognosis}

Since sepsis is a common, 'stand alone' diagnosis in neonatal foals, several studies have documented outcome. Survival rates in septic neonatal foals are highly variable, with reported short-term survival rates from 10 to $70 \%$ (Baker et al. 1986; Hoffman etal. 1992; Raisis et al. 1996b; Gayle etal. 1998; Stewart et al. 2002; Slack et al. 2005; Peek et al. 2006; Corley et al. 2007). However, outcome has improved significantly over time, which is likely due to early detection and treatment of at risk foals. In general, it is appropriate to quote a prognosis for short-term survival of approximately $50-60 \%$, but individual factors will greatly influence the outcome. Foals with Gram-negative or mixed organism infections are more likely to die than foals with Gram-positive infection (Barton et al. 1998; Corley et al. 2007). Odds of survival also decrease if septic arthritis is present, or if band neutrophils or serum creatinine concentration are significantly elevated (Sanchez et al. 2008). Neonatal foals with confirmed meningoencephalitis have a poor prognosis, with one study reporting an $11 \%$ survival rate despite aggressive treatment (Viu et al. 2012). There are few studies regarding long-term outcome in septic foals. One study reported that Thoroughbred foals with previous neonatal bacteraemia had significantly fewer racing wins and total earnings than siblings with no history of bacteraemia (Sanchez et al. 2008). A second study reported that the development of septic arthritis in Thoroughbred racehorses significantly decreased the likelihood that the horse would successfully race (Steel et al. 1999). Survival rates in mature horses with sepsis vary considerably with the primary disease process and are not always due to sepsis itself. Thus, it is difficult to prognosticate as no studies have been done to evaluate a large population of adult horses with the inclusion criteria of strictly SIRS or sepsis, regardless of the primary disease.

\section{Summary}

Sepsis is defined as SIRS due to infection, with bacterial infections predominating in equine cases. Sepsis continues to represent a major cause of morbidity and mortality in neonatal and mature horses. Although the word 'sepsis' has traditionally been used to describe bacteraemia and SIRS in neonatal foals, it is important to recognise that sepsis also occurs in mature horses, most commonly due to infectious enterocolitis, pleuropneumonia and metritis. Diagnosis of sepsis is difficult since SIRS criteria are nonspecific and microbial isolation and culture techniques are insensitive. Serum biomarkers are currently being investigated for their potential role in diagnosis and prognostication of sepsis. Successful treatment relies on rapid intervention, particularly with antimicrobial drugs to treat the primary disease, as well as hemodynamic support. The survival rate of septic neonatal foals ranges from approximately 30 to $85 \%$, while outcome in mature horses with sepsis depends on the primary infection, severity of disease and complication rate.

\section{Author's declaration of interests}

No conflicts of interest have been declared.

\section{Manufacturer's address}

'Idexx Laboratories, Inc., Westbrook, Maine, USA.

\section{References}

Abernathy-Young, K.K., LeBlanc, M.M., Embertson, R.M., Pierce, S.W. and Stromberg, A.J. (2012) Survival rates of mares and foals and postoperative complications and fertility of mares after cesarean section: 95 cases (1986-2000). J. Am. Vet. Med. Ass. 241, 927-934.

Adams, S.B. and Fessler, J.F. (1987) Umbilical cord remnant infections in foals: 16 cases (1975-1985). J. Am. Vet. Med. Ass. 190, 316-318.

Aguirre, C.N., Talavera, J. and Fernandez Del Palacio, M.J. (2013) Usefulness of Doppler ultrasonography to assess digital vascular dynamics in horses with systemic inflammatory response syndrome or laminitis. J. Am. Vet. Med. Ass. 243, 1756-1761.

Aikawa, N., Fujishima, S., Endo, S., Sekine, I., Kogawa, K., Yamamoto, Y., Kushimoto, S., Yukioka, H., Kato, N., Totsuka, K., Kikuchi, K., Ikeda, T., Ikeda, K., Harada, K. and Satomura, S. (2005) Multicenter prospective study of procalcitonin as an indicator of sepsis. J. Infect. Chemother. 11, 152-159.

Armengou, L., Monreal, L., Delgado, M.A., Rios, J., Cesarini, C. and Jose-Cunilleras, E. (2010) Low-molecular-weight heparin dosage in newborn foals. J. Vet. Intern. Med. 24, 1190-1195.

Armengou, L., Monreal, L., Tarancon, I., Navarro, M., Rios, J. and Segura, D. (2008) Plasma D-dimer concentration in sick newborn foals. J. Vet. Intern. Med. 22, 411-417.

Baker, S.M., Drummond, W.H., Lane, T.J. and Koterba, A.M. (1986) Follow-up evaluation of horses after neonatal intensive care. J. Am. Vet. Med. Ass. 189, 1454-1457.

Barton, M.H., Morris, D.D., Norton, N. and Prasse, K.W. (1998) Hemostatic and fibrinolytic indices in neonatal foals with presumed septicemia. J. Vet. Intern. Med. 12, 26-35.

Barton, M.H., Parviainen, A. and Norton, N. (2004) Polymyxin B protects horses against induced endotoxaemia in vivo. Equine Vet. J. 36 , 397-401. 
Batzofin, B.M., Sprung, C.L. and Weiss, Y.G. (2011) The use of steroids in the treatment of severe sepsis and septic shock. Best Pract. Res. Clin. Endocrinol. Metab. 25, 735-743.

Bazil, V., Horejsi, V., Baudys, M., Kristofova, H., Strominger, J.L., Kostka, W. and Hilgert, I. (1986) Biochemical characterization of a soluble form of the 53-kDa monocyte surface antigen. Eur. J. Immunol. 16 , 1583-1589.

Bedenice, D., Heuwieser, W., Brawer, R., Solano, M., Rand, W. and Paradis, M.R. (2003) Clinical and prognostic significance of radiographic pattern, distribution, and severity of thoracic radiographic changes in neonatal foals. J. Vet. Intern. Med. 17, 876-886.

Belgrave, R.L., Dickey, M.M., Arheart, K.L. and Cray, C. (2013) Assessment of serum amyloid A testing of horses and its clinical application in a specialized equine practice. J. Am. Vet. Med. Ass. 243, 113-119.

Bentz, A.I., Palmer, J.E., Dallap, B.L., Wilkins, P.A. and Boston, R.C. (2009) Prospective evaluation of coagulation in critically ill neonatal foals. J. Vet. Intern. Med. 23, 161-167.

Bertin, F.R., Reising, A., Slovis, N.M., Constable, P.D. and Taylor, S.D. (2013) Clinical and clinicopathological factors associated with survival in 44 horses with equine neorickettsiosis (Potomac horse Fever). J. Vet. Intern. Med. 27, 1528-1534.

Bone, R.C., Balk, R.A., Cerra, F.B., Dellinger, R.P., Fein, A.M., Knaus, W.A., Schein, R.M. and Sibbald, W.J. (1992) Definitions for sepsis and organ failure and guidelines for the use of innovative therapies in sepsis. The ACCP/SCCM Consensus Conference Committee. American College of Chest Physicians/Society of Critical Care Medicine. Chest 101, 1644-1655.

Borchers, A., Wilkins, P.A., Marsh, P.M., Axon, J.E., Read, J., Castagnetti, C., Pantaleon, L., Clark, C., Qura'n, L., Belgrave, R., Trachsel, D., Levy, M., Bedenice, D., Saulez, M.N. and Boston, R.C. (2012) Association of admission L-lactate concentration in hospitalised equine neonates with presenting complaint, periparturient events, clinical diagnosis and outcome: a prospective multicentre study. Equine Vet. J. 44, Suppl. 41, 57-63.

Borde, L., Amory, H., Grulke, S., Leroux, A.A., Houben, R.M., Detilleux, J. and Sandersen, C.C. (2014) Prognostic value of echocardiographic and Doppler parameters in horses admitted for colic complicated by systemic inflammatory response syndrome. J. Vet. Emerg. Crit. Care (San Antonio) 24, 302-310.

Brewer, B.D. and Koterba, A.M. (1988) Development of a scoring system for the early diagnosis of equine neonatal sepsis. Equine Vet. J. 20, 18-22.

Burton, A.B., Wagner, B., Erb, H.N. and Ainsworth, D.M. (2009) Serum interleukin-6 (IL-6) and IL-10 concentrations in normal and septic neonatal foals. Vet. Immunol. Immunopathol. 132, 122-128.

Castagnetti, C., Pirrone, A., Mariella, J. and Mari, G. (2010) Venous blood lactate evaluation in equine neonatal intensive care. Theriogenol. 73, 343-357.

Castagnetti, C., Mariella, J., Pirrone, A., Cinotti, S., Mari, G. and Peli, A. (2012) Expression of interleukin-lbeta, interleukin-8, and interferon-gamma in blood samples obtained from healthy and sick neonatal foals. Am. J. Vet. Res. 73, 1418-1427.

Chavatte, P.M., Roberts, B., Ousey, J.C., McGladdery, A.J. and Rossdale, P.D. (1992) Measurement of serum amyloid A protein (SAA) as an aid to differential diagnosis of infection in newborn foals. Proc. Sixth Int. Conf. Equine Infect. Dis. RW Publications, New Market. 6, 33-38.

Chavez-Bueno, S., Beasley, J.A., Goldbeck, J.M., Bright, B.C., Morton, D.J., Whitby, P.W. and Stull, T.L. (2011) Haptoglobin concentrations in preterm and term newborns. J. Perinatol. 31, 500-503.

Christoffersen, M., Baagoe, C.D., Jacobsen, S., Bojesen, A.M., Petersen, M.R. and Lehn-Jensen, H. (2010) Evaluation of the systemic acute phase response and endometrial gene expression of serum amyloid $A$ and pro- and anti-inflammatory cytokines in mares with experimentally induced endometritis. Vet. Immunol. Immunopathol. 138, 95-105.

Cohen, N.D., Parson, E.M., Seahorn, T.L. and Carter, G.K. (1994) Prevalence and factors associated with development of laminitis in horses with duodenitis/proximal jejunitis: 33 cases (1985-1991). J. Am. Vet. Med. Ass. 204, 250-254.
Cook, V.L., Holcombe, S.J., Gandy, J.C., Corl, C.M. and Sordillo, L.M. (2011) Ethyl pyruvate decreases proinflammatory gene expression in lipopolysaccharide-stimulated equine monocytes. Vet. Immunol. Immunopathol. 141, 92-99.

Corley, K.T.F. and Furr, M.O. (2003) Evaluation of a score designed to predict sepsis in foals. J. Vet. Emerg. Crit. Care 13, 149-155.

Corley, K.T., Donaldson, L.L. and Furr, M.O. (2005) Arterial lactate concentration, hospital survival, sepsis and SIRS in critically ill neonatal foals. Equine Vet. J. 37, 53-59.

Corley, K.T., Pearce, G., Magdesian, K.G. and Wilson, W.D. (2007) Bacteraemia in neonatal foals: clinicopathological differences between Gram-positive and Gram-negative infections, and single organism and mixed infections. Equine Vet. J. 39, 84-89.

Coutinho da Silva, M.A., Canisso, I.F., MacPherson, M.L., Johnson, A.E. and Divers, T.J. (2013) Serum amyloid A concentration in healthy periparturient mares and mares with ascending placentitis. Equine Vet. J. 45, 619-624.

Cronin, L., Cook, D.J., Carlet, J., Heyland, D.K., King, D., Lansang, M.A. and Fisher, C.J., Jr (1995) Corticosteroid treatment for sepsis: a critical appraisal and meta-analysis of the literature. Crit. Care Med. 23, 1430-1439.

Cywinska, A., Szarska, E., Gorecka, R., Witkowski, L., Hecold, M., Bereznowski, A., Schollenberger, A. and Winnicka, A. (2012) Acute phase protein concentrations after limited distance and long distance endurance rides in horses. Res. Vet. Sci. 93, 1402-1406.

Davenport, C.L., Boston, R.C. and Richardson, D.W. (2001) Effects of enrofloxacin and magnesium deficiency on matrix metabolism in equine articular cartilage. Am. J. Vet. Res. 62, 160-166.

Davis, J.L., Blikslager, A.T., Catto, K. and Jones, S.L. (2003) A retrospective analysis of hepatic injury in horses with proximal enteritis (1984-2002). J. Vet. Intern. Med. 17, 896-901.

de Laat, M.A., Sillence, M.N., McGowan, C.M. and Pollitt, C.C. (2012) Continuous intravenous infusion of glucose induces endogenous hyperinsulinaemia and lamellar histopathology in Standardbred horses. Vet. J. 191, 317-322.

Duggan, V. (2008) Serum amyloid A in the neonatal foal: the significance of peri-parturient events. Vet. J. 176, 267-269.

Elfenbein, J.R. and Sanchez, L.C. (2012) Prevalence of gastric and duodenal ulceration in 691 nonsurviving foals (1995-2006). Equine Vet. J. 44, Suppl. 41, 76-79.

Epstein, K.L. (2014) Coagulopathies in horses. Vet. Clin. N. Am.: Equine Pract. 30, 437-452.

Epstein, K.L., Brainard, B.M., Giguere, S., Vrono, Z. and Moore, J.N. (2013) Serial viscoelastic and traditional coagulation testing in horses with gastrointestinal disease. J. Vet. Emerg. Crit. Care (San Antonio) 23, 504-516.

Erdman, M.M., Creekmore, L.H., Fox, P.E., Pelzel, A.M., Porter-Spalding, B.A., Aalsburg, A.M., Cox, L.K., Morningstar-Shaw, B.R. and Crom, R.L. (2011) Diagnostic and epidemiologic analysis of the 2008-2010 investigation of a multi-year outbreak of contagious equine metritis in the United States. Prev. Vet. Med. 101, 219-228.

Ernst, N.S., Hernandez, J.A., MacKay, R.J., Brown, M.P., Gaskin, J.M., Nguyen, A.D., Giguere, S., Colahan, P.T., Troedsson, M.R., Haines, G.R., Addison, I.R. and Miller, B.J. (2004) Risk factors associated with fecal Salmonella shedding among hospitalized horses with signs of gastrointestinal tract disease. J. Am. Vet. Med. Ass. 225, 275-281.

Eurell, T.E., Wilson, D.A. and Baker, G.J. (1993) The effect of exploratory laparotomy on the serum and peritoneal haptoglobin concentrations of the pony. Can. J. Vet. Res. 57, 42-44.

Feary, D.J. and Hassel, D.M. (2006) Enteritis and colitis in horses. Vet. Clin. N. Am.: Equine Pract. 22, 437-479, ix.

Feige, K., Schwarzwald, C.C. and Bombeli, T. (2003) Comparison of unfractioned and low molecular weight heparin for prophylaxis of coagulopathies in 52 horses with colic: a randomised double-blind clinical trial. Equine Vet. J. 35, 506-513.

Fink, M.P. (2003) Ethyl pyruvate: a novel anti-inflammatory agent. Crit. Care Med. 31, S51-S56.

Fossum, C., Hjertner, B., Olofsson, K.M., Lindberg, R., Ahooghalandari, P., Camargo, M.M., Brojer, J., Edner, A. and Nostell, K. (2012) Expression of tIr4, md2 and cdl 4 in equine blood leukocytes during endotoxin infusion and in intestinal tissues from healthy horses. Vet. Immunol. Immunopathol. 150, 141-148. 
Frederick, J., Giguere, S. and Sanchez, L.C. (2009) Infectious agents detected in the feces of diarrheic foals: a retrospective study of 233 cases (2003-2008). J. Vet. Intern. Med. 23, 1254-1260.

Furr, M., Cohen, N.D., Axon, J.E., Sanchez, L.C., Pantaleon, L., Haggett, E., Campbell, R. and Tennent-Brown, B. (2012) Treatment with histamine-type 2 receptor antagonists and omeprazole increase the risk of diarrhoea in neonatal foals treated in intensive care units. Equine Vet. J. 44, Suppl. 41, 80-86.

Gayle, J.M., Cohen, N.D. and Chaffin, M.K. (1998) Factors associated with survival in septicemic foals: 65 cases (1988-1995). J. Vet. Intern. Med. 12, 140-146.

Gibbons, C., Dackor, R., Dunworth, W., Fritz-Six, K. and Caron, K.M. (2007) Receptor activity-modifying proteins: RAMPing up adrenomedullin signaling. Mol. Endocrinol. 21, 783-796.

Gohari, I.M., Arroyo, L., Macinnes, J.I., Timoney, J.F., Parreira, V.R. and Prescott, J.F. (2014) Characterization of Clostridium perfringens in the feces of adult horses and foals with acute enterocolitis. Can. J. Vet. Res. 78, 1-7.

Gold, J.R., Perkins, G.A., Erb, H.N. and Ainsworth, D.M. (2007) Cytokine profiles of peripheral blood mononuclear cells isolated from septic and healthy neonatal foals. J. Vet. Intern. Med. 21, 482-488.

Hart, K.A. and Barton, M.H. (2011) Adrenocortical insufficiency in horses and foals. Vet. Clin. N. Am.: Equine Pract. 27, 19-34.

Hart, K.A., Slovis, N.M. and Barton, M.H. (2009) Hypothalamicpituitary-adrenal axis dysfunction in hospitalized neonatal foals. J. Vet. Intern. Med. 23, 901-912.

Hart, K.A., Dirikolu, L., Ferguson, D.C., Norton, N.A. and Barton, M.H. (2012) Daily endogenous cortisol production and hydrocortisone pharmacokinetics in adult horses and neonatal foals. Am. J. Vet. Res. 73, 68-75.

Hart, K.A., Barton, M.H., Ferguson, D.C., Berghaus, R., Slovis, N.M. Heusner, G.L. and Hurley, D.J. (2011) Serum free cortisol fraction in healthy and septic neonatal foals. J. Vet. Intern. Med. 25, 345-355.

Hilton, H. and Pusterla, N. (2009) Intrapleural fibrinolytic therapy in the management of septic pleuropneumonia in a horse. Vet. Rec. 164 558-559.

Hinson, J.P., Kapas, S. and Smith, D.M. (2000) Adrenomedullin, a multifunctional regulatory peptide. Endocr. Rev. 21, 138-167.

Hofer, N., Zacharias, E., Muller, W. and Resch, B. (2012) An update on the use of C-reactive protein in early-onset neonatal sepsis: current insights and new tasks. Neonatol. 102, 25-36.

Hoffman, A.M., Staempfli, H.R. and Willan, A. (1992) Prognostic variables for survival of neonatal foals under intensive care. J. Vet. Intern. Med. 6, 89-95.

Hollis, A.R., Furr, M.O., Magdesian, K.G., Axon, J.E., Ludlow, V., Boston, R.C. and Corley, K.T. (2008a) Blood glucose concentrations in critically ill neonatal foals. J. Vet. Intern. Med. 22, 1223-1227.

Hollis, A.R., Wilkins, P.A., Palmer, J.E. and Boston, R.C. (2008b) Bacteremia in equine neonatal diarrhea: a retrospective study (1990-2007). J. Vet. Intern. Med. 22, 1203-1209.

Hudson, N.P., Prince, D.P., Mayhew, I.G. and Watson, E.D. (2005) Investigation and management of a cluster of cases of equine retained fetal membranes in Highland ponies. Vet. Rec. 157, 85-89.

Hulten, C. and Demmers, S. (2002) Serum amyloid A (SAA) as an aid in the management of infectious disease in the foal: comparison with total leucocyte count, neutrophil count and fibrinogen. Equine Vet. J. 34, 693-698.

Hulten, C., Sandgren, B., Skioldebrand, E., Klingeborn, B., Marhaug, G. and Forsberg, M. (1999) The acute phase protein serum amyloid A (SAA) as an inflammatory marker in equine influenza virus infection. Acta Vet. Scand. 40, 323-333.

Hulten, C., Gronlund, U., Hirvonen, J., Tulamo, R.M., Suominen, M.M., Marhaug, G. and Forsberg, M. (2002) Dynamics in serum of the inflammatory markers serum amyloid A (SAA), haptoglobin fibrinogen and alpha2-globulins during induced noninfectious arthritis in the horse. Equine Vet. J. 34, 699-704.

Hurcombe, S.D., Mudge, M.C. and Daniels, J.B. (2012) Presumptive bacterial translocation in horses with strangulating small intestinal lesions requiring resection and anastomosis. J. Vet. Emerg. Crit. Care (San Antonio) 22, 653-660.

Hurcombe, S.D., Toribio, R.E., Slovis, N., Kohn, C.W., Refsal, K., Saville, W. and Mudge, M.C. (2008) Blood arginine vasopressin, adrenocorticotropin hormone, and cortisol concentrations at admission in septic and critically ill foals and their association with survival. J. Vet. Intern. Med. 22, 639-647.

Jacobs, C.C., Holcombe, S.J., Cook, V.L., Gandy, J.C., Hauptman, J.G. and Sordillo, L.M. (2012) Ethyl pyruvate diminishes the inflammatory response to lipopolysaccharide infusion in horses. Equine Vet. J. 45 333-339.

Jacobsen, S., Thomsen, M.H. and Nanni, S. (2006) Concentrations of serum amyloid $\mathrm{A}$ in serum and synovial fluid from healthy horses and horses with joint disease. Am. J. Vet. Res. 67, 1738-1742.

Jeffcott, L.B. and Jeffcott, T.J. (1974) Studies on passive immunity in the foal. III. The characterization and significance of neonatal proteinuria. J. Comp. Pathol. 84, 455-465.

Keshet, R., Boursi, B., Maoz, R., Shnell, M. and Guzner-Gur, H. (2009) Diagnostic and prognostic significance of serum $C$-reactive protein levels in patients admitted to the department of medicine. Am. J. Med. Sci. 337, 248-255.

King, J.N. and Gerring, E.L. (1988) Detection of endotoxin in cases of equine colic. Vet. Rec. 123, 269-271.

Kitamura, K., Kangawa, K., Kawamoto, M., Ichiki, Y., Nakamura, S., Matsuo, H. and Eto, T. (1993) Adrenomedullin: a novel hypotensive peptide isolated from human pheochromocytoma. Biochem. Biophys. Res. Commun. 192, 553-560.

Kitchens, R.L. and Thompson, P.A. (2005) Modulatory effects of sCD14 and LBP on LPS-host cell interactions. J. Endotoxin Res. 11, 225-229.

Kitchens, R.L., Thompson, P.A., Viriyakosol, S., O'Keefe, G.E. and Munford, R.S. (2001) Plasma CD14 decreases monocyte responses to LPS by transferring cell-bound LPS to plasma lipoproteins. J. Clin. Invest. 108, 485-493.

Kjelgaard-Hansen, M. and Jacobsen, S. (2011) Assay validation and diagnostic applications of major acute-phase protein testing in companion animals. Clin. Lab. Med. 31, 51-70.

Knowles, E.J., Withers, J.M. and Mair, T.S. (2012) Increased plasma fructosamine concentrations in laminitic horses. Equine Vet. J. 44 226-229.

Koo, D.J., Zhou, M., Chaudry, I.H. and Wang, P. (2001) The role of adrenomedullin in producing differential hemodynamic responses during sepsis. J. Surg. Res. 95, 207-218.

Koterba, A.M., Brewer, B.D. and Tarplee, F.A. (1984) Clinical and clinicopathological characteristics of the septicaemic neonatal foal: review of 38 cases. Equine Vet. J. 16, 376-382.

Kullmann, A., Holcombe, S.J., Hurcombe, S.D., Roessner, H.A., Hauptman, J.G., Geor, R.J. and Belknap, J. (2013) Prophylactic digital cryotherapy is associated with decreased incidence of laminitis in horses diagnosed with colitis. Equine Vet. J. 46, 554-559.

Kwon, S., Moore, J.N., Robertson, T.P., Hurley, D.J., Wagner, B. and Vandenplas, M.L. (2013) Disparate effects of LPS infusion and carbohydrate overload on inflammatory gene expression in equine laminae. Vet. Immunol. Immunopathol. 155, 1-8.

Laborada, G., Rego, M., Jain, A., Guliano, M., Stavola, J., Ballabh, P., Krauss, A.N., Auld, P.A. and Nesin, M. (2003) Diagnostic value of cytokines and C-reactive protein in the first 24 hours of neonatal sepsis. Am. J. Perinatol. 20, 491-501.

Lavoie-Lamoureux, A., Leclere, M., Lemos, K., Wagner, B. and Lavoie, J.P. (2012) Markers of systemic inflammation in horses with heaves. J. Vet. Intern. Med. 26, 1419-1426.

Lopes, M.A., Salter, C.E., Vandenplas, M.L., Berghaus, R., Hurley, D.J. and Moore, J.N. (2010) Expression of inflammation-associated genes in circulating leukocytes collected from horses with gastrointestinal tract disease. Am. J. Vet. Res. 71, 915-924.

Luzzani, A., Polati, E., Dorizzi, R., Rungatscher, A., Pavan, R. and Merlini, A. (2003) Comparison of procalcitonin and C-reactive protein as markers of sepsis. Crit. Care Med. 31, 1737-1741.

MacKay, R.J. and Lester, G.D. (1992) Induction of the acute-phase cytokine, hepatocyte-stimulating factor/interleukin 6 , in the circulation of horses treated with endotoxin. Am. J. Vet. Res. 53, 1285-1289.

MacKay, R.J., Merritt, A.M., Zertuche, J.M., Whittington, M. and Skelley, L.A. (1991) Tumor necrosis factor activity in the circulation of horses given endotoxin. Am. J. Vet. Res. 52, 533-538.

Marik, P.E., Pastores, S.M., Annane, D., Meduri, G.U., Sprung, C.L., Arlt, W., Keh, D., Briegel, J., Beishuizen, A., Dimopoulou, I., Tsagarakis, S., 
Singer, M., Chrousos, G.P., Zaloga, G., Bokhari, F. and Vogeser, M. (2008) Recommendations for the diagnosis and management of corticosteroid insufficiency in critically ill adult patients: consensus statements from an international task force by the American College of Critical Care Medicine. Crit. Care Med. 36, 1937-1949.

Marsh, P.S. and Palmer, J.E. (2001) Bacterial isolates from blood and their susceptibility patterns in critically ill foals: 543 cases (1991-1998). J. Am. Vet. Med. Ass. 218, 1608-1610.

Meijer, M.C., van Weeren, P.R. and Rijkenhuizen, A.B. (2000) Clinical experiences of treating septic arthritis in the equine by repeated joint lavage: a series of 39 cases. J. Vet. Med. A Physiol. Pathol. Clin. Med. 47, 351-365.

Metzger, N., Hinchcliff, K.W., Hardy, J., Schwarzwald, C.C. and Wittum, T. (2006) Usefulness of a commercial equine lgG test and serum protein concentration as indicators of failure of transfer of passive immunity in hospitalized foals. J. Vet. Intern. Med. 20, 382-387.

Mizutani, A., Maeda, N., Toku, S., Higa-Nakamine, S., Isohama, Y., Sunakawa, H., Sugahara, K. and Yamamoto, H. (2011) Interaction of ethyl pyruvate in vitro with NF-kappaB subunits, RelA and p50. Eur. J. Pharmacol. 650, 151-156.

Morrison, D.C. and Jacobs, D.M. (1976) Binding of polymyxin B to the lipid A portion of bacterial lipopolysaccharides. Immunochemistry 13, 813-818.

Mussap, M., Noto, A., Cibecchini, F. and Fanos, V. (2013) The importance of biomarkers in neonatology. Semin. Fetal Neonatal Med. 18, 56-64.

Mutter, T.C., Ruth, C.A. and Dart, A.B. (2013) Hydroxyethyl starch (HES) versus other fluid therapies: effects on kidney function. Cochrane Database Syst. Rev. 7, CD007594.

Nieto, J.E., MacDonald, M.H., Braim, A.E. and Aleman, M. (2009) Effect of lipopolysaccharide infusion on gene expression of inflammatory cytokines in normal horses in vivo. Equine Vet. J. 41, 717-719.

Nishikimi, T., Yoshihara, F., Mori, Y., Kangawa, K. and Matsuoka, H. (2003) Cardioprotective effect of adrenomedullin in heart failure. Hypertens. Res. 26 (Suppl.), S121-S127.

Oncel, M.Y., Dilmen, U., Erdeve, O., Ozdemir, R., Calisici, E., Yurttutan, S., Canpolat, F.E., Oguz, S.S. and Uras, N. (2012) Proadrenomedullin as a prognostic marker in neonatal sepsis. Pediatr. Res. 72, 507-512.

Paltrinieri, S., Giordano, A., Villani, M., Manfrin, M., Panzani, S. and Veronesi, M.C. (2008) Influence of age and foaling on plasma protein electrophoresis and serum amyloid $\mathrm{A}$ and their possible role as markers of equine neonatal septicaemia. Vet. J. 176, 393-396.

Paradis, M.R. (1989) Infectious-diseases of the equine respiratory-tract from gestation to 5 months. Vet. Med. 84, $1174-1177$.

Parsons, C.S., Orsini, J.A., Krafty, R., Capewell, L. and Boston, R. (2007) Risk factors for development of acute laminitis in horses during hospitalization: 73 cases (1997-2004). J. Am. Vet. Med. Ass. 230 885-889.

Parviainen, A.K., Barton, M.H. and Norton, N.N. (2001) Evaluation of polymyxin $B$ in an ex vivo model of endotoxemia in horses. Am. J. Vet. Res. 62, 72-76.

Peek, S.F., Semrad, S., McGuirk, S.M., Riseberg, A., Slack, J.A., Marques, F., Coombs, D., Lien, L., Keuler, N. and Darien, B.J. (2006) Prognostic value of clinicopathologic variables obtained at admission and effect of antiendotoxin plasma on survival in septic and critically ill foals. J. Vet. Intern. Med. 20, 569-574.

Pepys, M.B., Baltz, M.L., Tennent, G.A., Kent, J., Ousey, J. and Rossdale, P.D. (1989) Serum amyloid A protein (SAA) in horses: objective measurement of the acute phase response. Equine Vet. J. 21, 106-109.

Perner, A., Haase, N., Guttormsen, A.B., Tenhunen, J., Klemenzson, G., Aneman, A., Madsen, K.R., Moller, M.H., Elkjaer, J.M., Poulsen, L.M., Bendtsen, A., Winding, R., Steensen, M., Berezowicz, P., Soe-Jensen, P., Bestle, M., Strand, K., Wiis, J., White, J.O., Thornberg, K.J., Quist, L., Nielsen, J., Andersen, L.H., Holst, L.B., Thormar, K., Kjaeldgaard, A.L., Fabritius, M.L., Mondrup, F., Pott, F.C., Moller, T.P., Winkel, P. and Wetterslev, J. (2012) Hydroxyethyl starch 130/0.42 versus Ringer's acetate in severe sepsis. N. Engl. J. Med. 367, 124-134.

Pernerstorfer, T., Stohlawetz, P., Hollenstein, U., Dzirlo, L., Eichler, H.G., Kapiotis, S., Jilma, B. and Speiser, W. (1999) Endotoxin-induced activation of the coagulation cascade in humans: effect of acetylsalicylic acid and acetaminophen. Arterioscler. Thromb. Vasc. Biol. 19, 2517-2523.
Pierrakos, C. and Vincent, J.L. (2010) Sepsis biomarkers: a review. Crit. Care 14, R15.

Pollock, P.J., Prendergast, M., Schumacher, J. and Bellenger, C.R. (2005) Effects of surgery on the acute phase response in clinically normal and diseased horses. Vet. Rec. 156, 538-542.

Pourcyrous, M., Bada, H.S., Korones, S.B., Baselski, V. and Wong, S.P. (1993) Significance of serial C-reactive protein responses in neonatal infection and other disorders. Pediatrics 92, 431-435.

Provencher, R., Threlfall, W.R., Murdick, P.W. and Wearly, W.K. (1988) Retained fetal membranes in the mare: a retrospective study. Can. Vet. J. 29, 903-910.

Pusterla, N., Magdesian, K.G., Mapes, S. and Leutenegger, C.M. (2006) Expression of molecular markers in blood of neonatal foals with sepsis. Am. J. Vet. Res. 67, 1045-1049.

Pusterla, N., Mapes, S., Wademan, C., White, A., Ball, R., Sapp, K., Burns, P., Ormond, C., Butterworth, K., Bartol, J. and Magdesian, K. (2013) Emerging outbreaks associated with equine coronavirus in adult horses. Vet. Microbiol. 162, 228-231.

Raisis, A.L., Hodgson, J.L. and Hodgson, D.R. (1996a) Equine neonatal septicaemia: 24 cases. Aust. Vet. J. 73, 137-140.

Raisis, A.L., Hodgson, J.L. and Hodgson, D.R. (1996b) Equine neonatal septicaemia: 24 cases. Aust. Vet. J. 73, 137-140.

Rohdich, N., Zschiesche, E., Heckeroth, A., Wilhelm, C., Leendertse, I. and Thomas, E. (2009) Treatment of septicaemia and severe bacterial infections in foals with a new cefquinome formulation: a field study. Dtsch Tierarztl. Wochenschr. 116, 316-320.

Russell, C.M., Axon, J.E., Blishen, A. and Begg, A.P. (2008) Blood culture isolates and antimicrobial sensitivities from 427 critically ill neonatal foals. Aust. Vet. J. 86, 266-271.

Ryu, S.H., Kim, J.G., Bak, U.B., Lee, C.W. and Lee, Y.L. (2004) A hematogenic pleuropneumonia caused by postoperative septic thrombophlebitis in a Thoroughbred gelding. J. Vet. Sci. 5, 75-77.

Sanchez, L.C. (2005) Equine neonatal sepsis. Vet. Clin. N. Am.: Equine Pract. 21, 273-293.

Sanchez, L.C., Giguere, S. and Lester, G.D. (2008) Factors associated with survival of neonatal foals with bacteremia and racing performance of surviving Thoroughbreds: 423 cases (1982-2007). J. Am. Vet. Med. Ass. 233, 1446-1452.

Schott, H.C., 2nd, Ewart, S.L., Walker, R.D., Dwyer, R.M., Dietrich, S., Eberhart, S.W., Kusey, J., Stick, J.A. and Derksen, F.J. (2001) An outbreak of salmonellosis among horses at a veterinary teaching hospital. J. Am. Vet. Med. Ass. 218, 1152-1159.

Schroeder, E.L., Holcombe, S.J., Cook, V.L., James, M.D., Gandy, J.C., Hauptman, J.G. and Sordillo, L.M. (2011) Preliminary safety and biological efficacy studies of ethyl pyruvate in normal mature horses. Equine Vet. J. 43, 341-347.

Schwarz, B.C., van den Hoven, R. and Schwendenwein, I. (2012) Diagnostic value of the neutrophil myeloperoxidase index in horses with systemic inflammation. Vet. J. 191, 72-78.

Semrad, S.D., Hardee, G.E., Hardee, M.M. and Moore, J.N. (1987) Low dose flunixin meglumine: effects on eicosanoid production and clinical signs induced by experimental endotoxaemia in horses. Equine Vet. J. 19, 201-206.

Senior, J.M., Proudman, C.J., Leuwer, M. and Carter, S.D. (2011) Plasma endotoxin in horses presented to an equine referral hospital: correlation to selected clinical parameters and outcomes. Equine vet. J. 43, 585-591.

Sevinga, M., Barkema, H.W. and Hesselink, J.W. (2002) Serum calcium and magnesium concentrations and the use of a calcium-magnesium-borogluconate solution in the treatment of Friesian mares with retained placenta. Theriogenol. 57, 941-947.

Sevinga, M., Barkema, H.W., Stryhn, H. and Hesselink, J.W. (2004) Retained placenta in Friesian mares: incidence, and potential risk factors with special emphasis on gestational length. Theriogenol. 61, 851-859.

Silva, A., Wagner, B., McKenzie, H.C., Desrochers, A.M. and Furr, M.O. (2013) An investigation of the role of soluble CD14 in hospitalized, sick horses. Vet. Immunol. Immunopathol. 155, 264-269.

Slack, J.A., McGuirk, S.M., Erb, H.N., Lien, L., Coombs, D., Semrad, S.D., Riseberg, A., Marques, F., Darien, B., Fallon, L., Burns, P., Murakami, M.A., Apple, F.S. and Peek, S.F. (2005) Biochemical markers of 
cardiac injury in normal, surviving septic, or nonsurviving septic neonatal foals. J. Vet. Intern. Med. 19, 577-580.

Steel, C.M., Hunt, A.R., Adams, P.L., Robertson, I.D., Chicken, C., Yovich, J.V. and Stick, J.A. (1999) Factors associated with prognosis for survival and athletic use in foals with septic arthritis: 93 cases (1987-1994). J. Am. Vet. Med. Ass. 215, 973-977.

Steverink, P.J., Salden, H.J., Sturk, A., Klein, W.R., van der Velden, M.A. and Nemeth, F. (1994) Laboratory and clinical evaluation of a chromogenic endotoxin assay for horses with acute intestinal disorders. Vet. Q. 16, 117-121.

Stewart, A.J., Hinchcliff, K.W., Saville, W.J., Jose-Cunilleras, E., Hardy, J. Kohn, C.W., Reed, S.M. and Kowalski, J.J. (2002) Actinobacillus sp. bacteremia in foals: clinical signs and prognosis. J. Vet. Intern. Med. 16, 464-471.

Stewart, J.H., Young, I.H., Rose, R.J., Costas, L. and Barko, A.M. (1987) The distribution of ventilation-perfusion ratios in the lungs of newborn foals. J. Dev. Physiol. 9, 309-324.

Stoneham, S.J., Palmer, L., Cash, R. and Rossdale, P.D. (2001) Measurement of serum amyloid $A$ in the neonatal foal using a latex agglutination immunoturbidimetric assay: determination of the normal range, variation with age and response to disease. Equine vet. J. 33, 599-603.

Sweeney, C.R., Divers, T.J. and Benson, C.E. (1985) Anaerobic bacteria in 21 horses with pleuropneumonia. J. Am. Vet. Med. Ass. 187, 721-724.

Sweeney, C.R., Holcombe, S.J., Barningham, S.C. and Beech, J. (1991) Aerobic and anaerobic bacterial isolates from horses with pneumonia or pleuropneumonia and antimicrobial susceptibility patterns of the aerobes. J. Am. Vet. Med. Ass. 198, 839-842.

Tadros, E.M. and Frank, N. (2012) Effects of continuous or intermittent lipopolysaccharide administration for 48 hours on the systemic inflammatory response in horses. Am. J. Vet. Res. 73, 1394-1402.

Taylor, S.D. (2014) Biomarkers in equine sepsis. In: American College of Veterinary Internal Medicine Forum, Nashville, Tennessee. www.acvim.org.

Taylor, S.D., Zabrecky, K.A., Slovis, N.M. and Constable, P.D. (2013) Plasma C-reactive protein concentrations in critically ill neonatal foals. In: Conference of Research Workers in Animal Disease, Chicago, Illinois. pp 122-123.

Taylor, F.B., Jr, Toh, C.H., Hoots, W.K., Wada, H. and Levi, M. (2001) Towards definition, clinical and laboratory criteria, and a scoring system for disseminated intravascular coagulation. Thromb. Haemost. 86, 1327-1330.

Theelen, M.J., Wilson, W.D., Edman, J.M., Magdesian, K.G. and Kass, P.H. (2014a) Temporal trends in in vitro antimicrobial susceptibility patterns of bacteria isolated from foals with sepsis: 1979-2010. Equine Vet. J. 46, 161-168.

Theelen, M.J., Wilson, W.D., Edman, J.M., Magdesian, K.G. and Kass, P.H. (2014b) Temporal trends in prevalence of bacteria isolated from foals with sepsis: 1979-2010. Equine Vet. J. 46, 169-173.

Toth, B., Slovis, N.M., Constable, P.D. and Taylor, S.D. (2014) Plasma adrenomedullin concentrations in critically ill neonatal foals. J. Vet. Intern. Med. 28, 1294-1300.

Turek, J.J., Templeton, C.B., Bottoms, G.D. and Fessler, J.F. (1985) Flunixin meglumine attenuation of endotoxin-induced damage to the cardiopulmonary vascular endothelium of the pony. Am. J. Vet. Res. 46, 591-596.

Ueda, S., Nishio, K., Minamino, N., Kubo, A., Akai, Y., Kangawa, K. Matsuo, H., Fujimura, Y., Yoshioka, A., Masui, K., Doi, N., Murao, Y. and
Miyamoto, S. (1999) Increased plasma levels of adrenomedullin in patients with systemic inflammatory response syndrome. Am. J. Respir. Crit. Care Med. 160, 132-136.

Vandenplas, M.L., Moore, J.N., Barton, M.H., Roussel, A.J. and Cohen, N.D. (2005) Concentrations of serum amyloid $A$ and lipopolysaccharide-binding protein in horses with colic. Am. J. Vet. Res. 66, 1509-1516.

Vigushin, D.M., Pepys, M.B. and Hawkins, P.N. (1993) Metabolic and scintigraphic studies of radioiodinated human C-reactive protein in health and disease. J. Clin. Invest. 91, 1351-1357.

Vincent, J.L., Donadello, K. and Schmit, X. (2011) Biomarkers in the critically ill patient: C-reactive protein. Crit. Care Clin. 27, 241-251.

Vinogradov, E., MacLean, L.L., Brooks, B.W., Lutze-Wallace, C. and Perry, M.B. (2008) Structure of the O-polysaccharide of the lipopolysaccharide produced by Taylorella asinigenitalis type strain (ATCC 700933). Biochem. Cell Biol. 86, 278-284.

Visser, M.B. and Pollitt, C.C. (2011) Lamellar leukocyte infiltration and involvement of IL-6 during oligofructose-induced equine laminitis development. Vet. Immunol. Immunopathol. 144, 120-128.

Viu, J., Monreal, L., Jose-Cunilleras, E., Cesarini, C., Anor, S. and Armengou, L. (2012) Clinical findings in 10 foals with bacterial meningoencephalitis. Equine Vet. J. 44, Suppl. 41, 100-104.

Wagner, B., Ainsworth, D.M. and Freer, H. (2013) Analysis of soluble CD14 and its use as a biomarker in neonatal foals with septicemia and horses with recurrent airway obstruction. Vet. Immunol. Immunopathol. 155, 124-128.

Wang, P., Ba, Z.F., Cioffi, W.G., Bland, K.I. and Chaudry, I.H. (1998) The pivotal role of adrenomedullin in producing hyperdynamic circulation during the early stage of sepsis. Arch. Surg. 133, 1298-1304.

Ward, D.S., Fessler, J.F., Bottoms, G.D. and Turek, J. (1987) Equine endotoxemia: cardiovascular, eicosanoid, hematologic, blood chemical, and plasma enzyme alterations. Am. J. Vet. Res. 48 , $1150-1156$.

Welch, R.D., Watkins, J.P., Taylor, T.S., Cohen, N.D. and Carter, G.K. (1992) Disseminated intravascular coagulation associated with colic in 23 horses (1984-1989). J. Vet. Intern. Med. 6, 29-35.

Werners, A.H. and Bryant, C.E. (2012) Pattern recognition receptors in equine endotoxaemia and sepsis. Equine Vet. J. 44, 490-498.

Werners, A.H., Bull, S. and Fink-Gremmels, J. (2005) Endotoxaemia: a review with implications for the horse. Equine Vet. J. 37, 371-383.

Wilson, W.D. and Madigan, J.E. (1989) Comparison of bacteriologic culture of blood and necropsy specimens for determining the cause of foal septicemia: 47 cases (1978-1987). J. Am. Vet. Med. Ass. 195 1759-1763.

Wong, D.M., Sponseller, B.A., Alcott, C.J., Agbedanu, P.N., Wang, C. and Hsu, W.H. (2013) Effects of intravenous administration of polymyxin $B$ in neonatal foals with experimental endotoxemia. J. Am. Vet. Med. Ass. 243, 874-881.

Zabrecky, K.A., Slovis, N.M., MacGillivray, K.C., Frazer, M.L., Sprayberry, K.A., Constable, P.D. and Taylor, S.D. (2013) Plasma C-reactive protein and haptoglobin concentrations in critically ill neonatal foals. In: Dorothy Russell Havemeyer Foundation Equine Neonatal Sepsis Workshop VI, Saugerties, New York.

Zimmerman, J.L. (2004) Use of blood products in sepsis: an evidence-based review. Crit. Care Med. 32, S542-S547. 